\title{
Metallosurfactants of chromium(III) coordination complexes. Synthesis, characterization and determination of $\mathrm{CMC}$ values
}

\author{
Narayanasamy Kumaraguru and Sankarlingam Arunachalam \\ School of Chemistry, Bharathidasan University, Tiruchirappalli 620 024, Tamil Nadu, India \\ Mahadevimanglam Narayanasamy Arumugham \\ Department of Chemistry, Vellore Institute of Technology, Vellore 632 014, Tamil Nadu, India \\ Kannappan Santhakumar* \\ Ecole Polytechnique Fédérale de Lausanne, EPFL-ENAC-LPAS, Station 6, CH-1015, Lausanne Switzerland
}

Received 24 October 2005; accepted 16 November 2005

\begin{abstract}
A number of mixed ligand chromium(III)-surfactant coordination complexes, of the type cis- $\left.^{-} \mathrm{Cr}(\mathrm{en})_{2}(\mathrm{~A}) \mathrm{X}\right]^{2+}$ and cis- $\alpha-[\mathrm{Cr}(\operatorname{trien})(\mathrm{A}) \mathrm{X}]^{2+}\left(\mathrm{A}=\right.$ Dodecyl or Cetylamine; $\left.\mathrm{X}=\mathrm{F}^{-}, \mathrm{Cl}^{-}, \mathrm{Br}^{-}\right)$were synthesized from the corresponding dihalogeno complexes by ligand substitution. These compounds form foam in aqueous solution when shaken. The critical micelle concentration (CMC) values of these surfactant metal complexes in aqueous solution were obtained from conductance measurements. Specific conductivity data (at 303, 308 and $313 \mathrm{~K}$ ) served for evaluation of the temperature-dependent critical micelle concentration $(\mathrm{cmc})$ and the thermodynamics of micellization $\left(\Delta G_{\mathrm{m}}^{0}, \Delta H_{\mathrm{m}}^{0}\right.$ and $\left.\Delta S_{\mathrm{m}}^{0}\right)$.
\end{abstract}

\section{Introduction}

Cationic surfactants became important because of their bacteriostatic properties. They have been introduced into several commercial products such as antiseptic agents in cosmetics and as germicides [1]. Cationic surfactants have also found a wide range of applications because of their unique solution properties such as detergency, solublization and surface wetting capabilities, in diverse areas such as mining, petroleum, and pharmaceutical industries, chemical as well as biochemical research [2] and as catalyst in several organic and inorganic reactions [3]. Studies on the chemistry of metallomicelles have received a substained high level of attention from the scientific community for the last few years [4-15] due to their relevance in various redox processes in biological systems, and acting as promising agents for anthelmintic [16], antiparasitic [17] and antibiotics [18].

The metal-surfactant complex is a special type of surfactant, where a coordination complex (containing a central metal ion with surrounding ligands coordinated to the metal) acts as the surfactant (Scheme 1). In these surfactants the metal complex entity containing the central metal ion with its primary coordination sphere acts as the head group and the hydrophobic entity of one or more ligands acts as the tail part. There are but a few reports [10] of the synthesis, isolation and

\footnotetext{
* Author for correspondence: E-mail: lovingsantha@yahoo.com
}

characterization of surfactant transition metal complexes, in contrast to numerous reports of the formation and study of such surfactants in solution without isolation [10]. It is argued that the high charge and size of the head group of the complex having long paraffin tails, detergent-like characteristics are able to penetrate biological membranes and destabilize the exterior membrane of the organism [19, 20]. Moreover, transition metal ion complexes with lipophilic ligands in micellar or vesicular aggregates have attracted considerable attention as catalyst for the cleavage of esters and amides and as biomimetic models of hydrolytic metalloenzymes [21, 22]. Recently there has been increasing interest in the use of these organized media to study the fundamental photochemical reactions of metal complexes relevant to the conversion of solar energy into other useful forms of energy through photochemical reactions $[23,24]$. As part of our studies on transition metal-based surfactants [6,7] in this paper we report the synthesis, characterization and determination of critical micelle concentration values of some novel chromium(III) surfactant complexes.

\section{Experimental}

\section{Chemicals and reagents}

All the reagents were of analytical grade (Aldrich and Merck). Ultra-pure water, obtained by deionising distilled $\mathrm{H}_{2} \mathrm{O}$ using a Milli-Q Reagent Grade water system, 


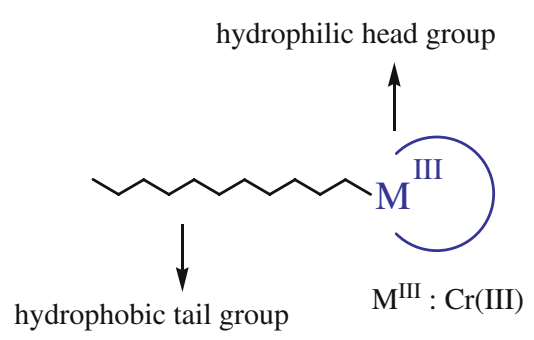

Metallosurfactant

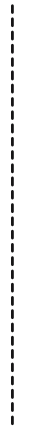

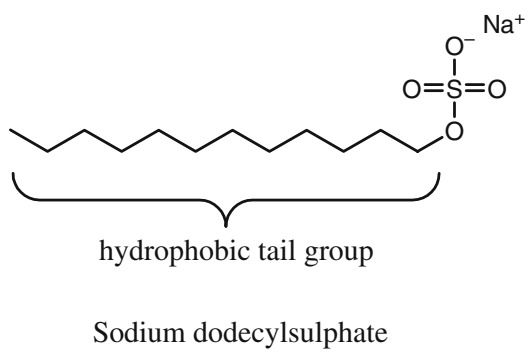

Scheme 1 .

was used for preparative work and to make up solutions for all physical measurements.

\section{Synthesis of metallosurfactants of chromium(III) complexes}

The surfactant chromium(III) complexes synthesized here, were prepared in a similar way to those complexes reported in the literature [25-28], by replacing the onehalogen ion by long-chain amine ligands as follows.

\section{Synthesis of bis-ethylenediamine chromium(III) metallosurfactants}

cis- $\left[\mathrm{Cr}(\mathrm{en})_{2}\left(\mathrm{C}_{12} \mathrm{H}_{25} \mathrm{NH}_{2}\right) \mathrm{F}\right]\left(\mathrm{ClO}_{4}\right)_{2}$ and cis- $\left[\mathrm{Cr}(\mathrm{en})_{2}-\right.$ $\left.\left(\mathrm{C}_{16} \mathrm{H}_{33} \mathrm{NH}_{2}\right) \mathrm{F}\right]\left(\mathrm{ClO}_{4}\right)_{2}: \quad$ cis-[Cr(en) $\left.)_{2} \mathrm{~F}_{2}\right] \mathrm{Cl} \quad$ [25] (3 g) were dissolved in $\mathrm{H}_{2} \mathrm{O}\left(20 \mathrm{~cm}^{3}\right)$. To this solution slightly more than the calculated amount of dodecylamine $\left(3 \mathrm{~cm}^{3}\right)$, where the amine used was not sufficiently miscible with (soluble in) $\mathrm{H}_{2} \mathrm{O}$, was first mixed with $\mathrm{EtOH}$ $\left(2 \mathrm{~cm}^{3}\right)$ and was then added drop-by-drop for a period of $30 \mathrm{~min}$. The purple solution gradually became lighter during the reaction. The mixture was set aside at $313 \mathrm{~K}$ for 2 days until no further change was observed. Afterwards a saturated solution of $\mathrm{NaClO}_{4}$ in very dilute $\mathrm{HClO}_{4}$ acid was added. Slowly a pasty solid mass separated. It was filtered-off, washed with small amounts of alcohol, followed by acetone, and then dried in air. The semi-dried solid was further dried in a drying pistol over fused $\mathrm{CaCl}_{2}$ and stored in a vacuum desiccator. The same procedure was followed for the cis- $\left[\mathrm{Cr}(\mathrm{en})_{2}\left(\mathrm{C}_{16} \mathrm{H}_{33} \mathrm{NH}_{2}\right) \mathrm{F}\right]\left(\mathrm{ClO}_{4}\right)_{2}$ complexes: instead of dodecylamine, cetylamine was used.

The cis- $\left[\mathrm{Cr}(\mathrm{en})_{2}\left(\mathrm{C}_{12} \mathrm{H}_{25} \mathrm{NH}_{2}\right) \mathrm{Cl}\right]\left(\mathrm{ClO}_{4}\right)_{2}$ and cis$\left[\mathrm{Cr}(\mathrm{en})_{2}\left(\mathrm{C}_{16} \mathrm{H}_{33} \mathrm{NH}_{2}\right) \mathrm{Cl}\right]\left(\mathrm{ClO}_{4}\right)_{2} \quad$ cis- $\left[\mathrm{Cr}(\mathrm{en})_{2}\left(\mathrm{C}_{12} \mathrm{H}_{25}\right.\right.$ $\left.\left.\mathrm{NH}_{2}\right) \mathrm{Br}\right]\left(\mathrm{ClO}_{4}\right)_{2}$ and cis- $\left[\mathrm{Cr}(\mathrm{en})_{2}\left(\mathrm{C}_{16} \mathrm{H}_{33} \mathrm{NH}_{2}\right) \mathrm{Br}\right]\left(\mathrm{ClO}_{4}\right)_{2}$ complexes were prepared from the corresponding parent compounds $[25,26]$ by adopting the same method as described above.

\section{Synthesis of triethylenetetramine chromium (III) metallosurfactants}

The complexes of the type cis- $\alpha-[\mathrm{Cr}(\operatorname{trien}) \mathrm{AX}]\left(\mathrm{ClO}_{4}\right)_{2}$, $(\mathrm{X}=\mathrm{F}, \mathrm{Cl}, \mathrm{Br} ; \mathrm{A}=$ dodecyl/cetylamine $)$ were prepared by ligand substitution by replacing halogen ion with dodecylamine/cetylamine from the corresponding cis- $\alpha-\left[\mathrm{Cr}(\operatorname{trien}) \mathrm{F}_{2}\right] \mathrm{Cl}, \quad$ cis- $\alpha-\left[\mathrm{Cr}(\operatorname{trien}) \mathrm{Cl}_{2}\right] \mathrm{Cl}, \quad$ cis- $\alpha-$ $\left[\mathrm{Cr}(\operatorname{trien}) \mathrm{Br}_{2}\right] \mathrm{Br}$ complexes similar to those reported in the literature [27, 28].

Safety Note: Perchlorate salts of metal complexes with organic ligands are potentially explosive. Only small amounts of material should be prepared, and should be handled with caution.

\section{Instrumentation}

Infrared (IR) spectra were recorded on a Jasco FT/IR - 460 plus spectrometer using the $\mathrm{KBr}$ disc method. ${ }^{1} \mathrm{H}$ NMR spectra were recorded in appropriate deuteriated solvents using a Bruker $\mathrm{AC} 300 \mathrm{~F}(300 \mathrm{MHz})$ spectrometer with TMS as internal reference. Electronic absorption spectra were taken in $10^{-3} \mathrm{M} \mathrm{HClO}_{4}$ medium recorded in a Varian Cary 500 Scan UV-VisNIR spectrophotometer. $\mathrm{C}, \mathrm{H}$ and $\mathrm{N}$ were estimated using a Perkin Elmer $2400 \mathrm{CHN}$ instrument. Conductivity studies were done in aqueous solutions of the complexes with an Elico-CM 180 conductivity bridge and a dip-type cell with a cell constant of 1.0.

\section{Determination of $C M C$}

The critical micelle concentration values of these complexes were measured conductometrically using a specific conductivitymeter. The conductivity cell was calibrated with $\mathrm{KCl}$ solutions in the appropriate concentration range. The cell constant was calculated using molar conductivity data for $\mathrm{KCl}$ published by Shedluosky [29] and Chambers et al [30]. Various concentrations of chromium(III)-surfactant complexes were prepared in the $10^{-5}-10^{-1} \mathrm{~mol} \mathrm{dm}^{-3}$ range in aqueous solution. The conductivities of these solutions were measured at 303, 308 and $313 \mathrm{~K}$. The temperature of the thermostat was maintained constant within $\pm 0.01 \mathrm{~K}$. At least one set of 50 specific conductance readings for 50 different concentrations of complex was recorded in order to get the critical micelle concentration values for each system.

\section{Results and discussion}

The chromium(III)-surfactant complexes synthesized in the present study were characterized by UV-Visible, 
IR and checked by comparing the spectra with those for the corresponding ordinary complexes where one of the ligands is butylamine, instead of dodecylamine/ cetylamine and those reported earlier for similar type of cobalt(III) complexes [6,7]. The purity of the complexes was checked by chromium [25], elemental and halide analyses, and was found to be in good agreement with that of the calculated value (Table 1).

The uniqueness of the chromium(III)-surfactant coordination complexes lies in the fact that the bond between the head group and the tail part of the surfactant-chromium(III) complex is a coordinate bond and the surfactant contains a higher charge on the head group unlike common surfactants (SDS). At the same time like the common surfactants, these chromium(III)-surfactant coordination compounds form foam in aqueous solution when mechanically disturbed like shaking, and these complexes dissolve slowly in water. Sometimes it is necessary to sonicate to get a homogeneous solution.

\section{Spectroscopic characterization}

Several attempts have been made to relate differences in the infrared spectra to the geometrical configuration structure of the complexes [31-36]. For the assignment of geometrical configuration to these complexes, infrared spectroscopy was used. Various workers have employed [31-36] the $\mathrm{NH}_{2}$ deformation mode in the $1700-1500 \mathrm{~cm}^{-1}$ region, $\mathrm{CH}_{2}$ rocking mode in the $900-850 \mathrm{~cm}^{-1}$ and $\mathrm{M}-\mathrm{N}$ stretching mode in the $610-500 \mathrm{~cm}^{-1}$ region to distinguish between the cis- and trans-isomers of chromium(III)-ethylenediamine complexes. Baldwin [34] suggested that the most consistent variations between the spectra of cisand trans-isomers were found in the $\mathrm{CH}_{2}$ rocking region $\left(900-850 \mathrm{~cm}^{-1}\right)$. The cis-isomers always show two peaks, whereas the trans-isomers usually have only one. Hughes and McWhinnie [32] studied the infrared absorption spectra of several bis-ethylenediamine complexes and obtained a satisfactory correlation in the $610-500 \mathrm{~cm}^{-1}$ region, where $\mathrm{M}-\mathrm{N}$ stretching modes of the chelate ring occur. Here, no trans-isomers had more than three strong bands, whereas all cis-isomers had at least four, sometimes occurring as shoulders. The bands for the trans-isomers were generally evenly distributed, while those for cis-complexes occurred in two groups with wide separation between them. The IR data indicate that generally the complexes studied followed the previous trends. Because of lower symmetry in the present study, the cis-isomers show two bands for the $\mathrm{NH}_{2}$ deformation, two bands for the $\mathrm{NH}_{2}$ wagging modes, two bands for $\mathrm{CH}_{2}$ rocking mode and four bands occurring as groups of two with wide separation for the M-N stretching mode. Complex of the type cis- $\alpha-$ $[\mathrm{M}(\operatorname{trien}) \mathrm{XCl}]^{\mathrm{n}+}$ of the present study showed two bands for the $\mathrm{NH}_{2}$ deformation in the $1630-1580 \mathrm{~cm}^{-1}$ region, two bands for the $\mathrm{CH}_{2}$ or $\mathrm{NH}_{2}$ twist mode in the $1150-980 \mathrm{~cm}^{-1}$ region, and the $\mathrm{CH}_{2}$ rock mode in the $940-860 \mathrm{~cm}^{-1}$ region appeared as two bands. The spectroscopic details, therefore clearly indicate a cis configuration for the chromium(III)-ethylenediamine and a cis- $\alpha$ configuration for chromium(III)-triethylenetetramine type of surfactant complexes.

The ${ }^{1} \mathrm{H}-\mathrm{NMR}$ spectrum offers conclusive proof of the configuration for the isomers in solution. The cis and trans-isomers of the $\left[\mathrm{M}(\mathrm{en})_{2} \mathrm{X}_{2}\right]^{+}$ions have different symmetry properties, and this factor appears to govern the differences in their NMR spectra. The cisisomers possess $\mathrm{C}_{2}$-symmetry with the two-fold axis in the plane of chromium and the two $\mathrm{X}$ groups and this makes $-\mathrm{CH}_{2} \mathrm{CH}_{2}-$ groups equivalent, provided that the chromium-ethylenediamine rings have the same conformation. Moreover, in complexes of the type cis- $\left[\mathrm{M}(\mathrm{en})_{2} \mathrm{X}_{2}\right]^{\mathrm{n}+}$ there are four pairs of equivalent nitrogen protons, whereas in complexes of the type cis- $\left[\mathrm{M}(\mathrm{en})_{2} \mathrm{XY}\right]^{\mathrm{n}+}$, although some protons are similarly orientated, no two protons are in identical situations. In complexes of the type trans- $\left[\mathrm{M}(\mathrm{en})_{2} \mathrm{X}_{2}\right]^{\mathrm{n}+}$ all the protons are equivalent, but in complexes of the type trans- $\left[\mathrm{M}(\mathrm{en})_{2} \mathrm{XY}\right]^{\mathrm{n}+}$ the protons on one side of the plane of the ethylenediamine ring will all experience a different field from those on the other side. It is possible that if the ligands $\mathrm{X}$ and $\mathrm{Y}$ differed greatly in size, inversion of the chelate ring would be hindered or

Table 1. Microanalysis and visible spectra of metallosurfactants of chromium(III) complexes

\begin{tabular}{|c|c|c|c|c|c|c|c|}
\hline \multirow[t]{2}{*}{ Metallosurfactants } & \multirow[t]{2}{*}{$\lambda_{\max }(\mathrm{nm})$} & \multirow[t]{2}{*}{ Yield $(\%)$} & \multicolumn{5}{|c|}{ (\%) Found (Calcd) } \\
\hline & & & $\mathrm{Cr}$ & $\mathrm{C}$ & $\mathrm{H}$ & $\mathrm{N}$ & $\mathrm{F} / \mathrm{Cl} / \mathrm{Br}$ \\
\hline cis- $\left[\mathrm{Cr}(\mathrm{en})_{2}\left(\mathrm{C}_{12} \mathrm{H}_{25} \mathrm{NH}_{2}\right) \mathrm{F}\right]\left(\mathrm{ClO}_{4}\right)_{2}$ & 520 & 57 & $8.9(9.1)$ & $33.5(33.6)$ & $7.7(7.6)$ & $12.2(12.3)$ & $3.0(3.3)$ \\
\hline cis- $\left[\mathrm{Cr}(\mathrm{en})_{2}\left(\mathrm{C}_{12} \mathrm{H}_{25} \mathrm{NH}_{2}\right) \mathrm{Cl}\right]\left(\mathrm{ClO}_{4}\right)_{2}$ & 525 & 60 & $8.7(8.8)$ & $32.6(32.7)$ & $7.3(7.4)$ & $12.0(11.9)$ & $5.8(6.0)$ \\
\hline$c i s-\left[\mathrm{Cr}(\mathrm{en})_{2}\left(\mathrm{C}_{12} \mathrm{H}_{25} \mathrm{NH}_{2}\right) \mathrm{Br}\right]\left(\mathrm{ClO}_{4}\right)_{2}$ & 528 & 55 & $8.1(8.2)$ & $30.4(30.4)$ & $6.8(6.8)$ & $10.9(11.1)$ & $12.2(12.6)$ \\
\hline$c i s-\left[\mathrm{Cr}(\mathrm{en})_{2}\left(\mathrm{C}_{16} \mathrm{H}_{33} \mathrm{NH}_{2}\right) \mathrm{F}\right]\left(\mathrm{ClO}_{4}\right)_{2}$ & 518 & 62 & $8.3(8.3)$ & $38.2(38.3)$ & $8.0(8.1)$ & $11.0(11.2)$ & $2.9(3.0)$ \\
\hline$c i s-\left[\mathrm{Cr}(\mathrm{en})_{2}\left(\mathrm{C}_{16} \mathrm{H}_{33} \mathrm{NH}_{2}\right) \mathrm{Cl}\right]\left(\mathrm{ClO}_{4}\right)_{2}$ & 524 & 53 & $8.0(8.0)$ & $37.1(37.3)$ & $7.7(7.9)$ & $10.7(10.9)$ & $5.5(5.5)$ \\
\hline cis- $\left[\mathrm{Cr}(\mathrm{en})_{2}\left(\mathrm{C}_{16} \mathrm{H}_{33} \mathrm{NH}_{2}\right) \mathrm{Br}\right]\left(\mathrm{ClO}_{4}\right)_{2}$ & 526 & 60 & $7.5(7.6)$ & $35.0(34.9)$ & $7.4(7.4)$ & $10.2(10.2)$ & $11.2(11.6)$ \\
\hline$c i s-\alpha-\left[\mathrm{Cr}(\operatorname{trien})\left(\mathrm{C}_{12} \mathrm{H}_{25} \mathrm{NH}_{2}\right) \mathrm{F}\right]\left(\mathrm{ClO}_{4}\right)_{2}$ & 530 & 65 & $8.5(8.6)$ & $35.7(35.9)$ & $7.4(7.5)$ & $11.5(11.6)$ & $2.9(3.2)$ \\
\hline$c i s-\alpha-\left[\mathrm{Cr}(\operatorname{trien})\left(\mathrm{C}_{12} \mathrm{H}_{25} \mathrm{NH}_{2}\right) \mathrm{Cl}\right]\left(\mathrm{ClO}_{4}\right)_{2}$ & 533 & 60 & $8.3(8.4)$ & $35.1(34.9)$ & $7.2(7.3)$ & $11.1(11.3)$ & $5.4(5.7)$ \\
\hline$c i s-\alpha-\left[\mathrm{Cr}(\operatorname{trien})\left(\mathrm{C}_{12} \mathrm{H}_{25} \mathrm{NH}_{2}\right) \mathrm{Br}\right]\left(\mathrm{ClO}_{4}\right)_{2}$ & 535 & 55 & $7.9(7.8)$ & $32.4(32.6)$ & $6.8(6.8)$ & $10.4(10.6)$ & $11.7(12.0)$ \\
\hline$c i s-\alpha-\left[\mathrm{Cr}(\operatorname{trien})\left(\mathrm{C}_{16} \mathrm{H}_{33} \mathrm{NH}_{2}\right) \mathrm{F}\right]\left(\mathrm{ClO}_{4}\right)_{2}$ & 528 & 57 & $7.8(7.9)$ & $40.2(40.2)$ & $8.0(8.1)$ & $10.5(10.7)$ & $2.6(2.9)$ \\
\hline$c i s-\alpha-\left[\mathrm{Cr}(\operatorname{trien})\left(\mathrm{C}_{16} \mathrm{H}_{33} \mathrm{NH}_{2}\right) \mathrm{Cl}\right]\left(\mathrm{ClO}_{4}\right)_{2}$ & 530 & 62 & $7.5(7.7)$ & $39.1(39.2)$ & $8.0(7.9)$ & $10.4(10.4)$ & $5.3(5.3)$ \\
\hline cis- $\alpha-\left[\mathrm{Cr}(\operatorname{trien})\left(\mathrm{C}_{16} \mathrm{H}_{33} \mathrm{NH}_{2}\right) \mathrm{Br}\right]\left(\mathrm{ClO}_{4}\right)_{2}$ & 533 & 55 & $7.0(7.2)$ & $36.8(36.7)$ & $7.5(7.4)$ & $9.5(9.7)$ & $10.8(11.1)$ \\
\hline
\end{tabular}


even inhibited. In the case of trans complexes, two separate proton resonances of equal area would be observed if inversion was inhibited, while with cis complexes a most complex pattern would result. In trans-isomers, however, with $\mathrm{D}_{2 \mathrm{~h}}$ symmetry, the amine protons and methylene protons of ethylenediamine appear as a singlet at $3 \mathrm{ppm}$. In the present study, the cis complexes (Figure 1), due to the lower symmetry, methylene protons of ethylenediamine show more complex absorption around 2.6-2.8 ppm. The methylene protons of the long chain moieties (dodecylamine/ cetylamine) give rise to a multiplet usually at $1.25-1.9 \mathrm{ppm}$, whereas the terminal methyl group of the hydrocarbon chain substituent gives a triplet at $0.80 \mathrm{ppm}$. The ${ }^{1} \mathrm{H}-\mathrm{NMR}$ spectral data for the chromium(III)-triethylenetetramine complexes exhibit signals in the region $2.5-3.0 \mathrm{ppm}$ attributable to the $-\mathrm{CH}_{2}$ group of the triethylenetetramine chelate ring, thus confirming the cis structure of the complex.

The wavelength of the first absorption maximum in aqueous acid medium for each complex is given in Table 1. The spectra obtained were compared with the spectra of the corresponding butylamine complexes [37], it reveals that both the ordinary and the surfactant complexes have the same structure and the replacement of lower aliphatic amine ligands by long chain aliphatic amine ligands does not affect the symmetry of the surfactant complexes.

\section{Critical micelle concentration values (CMC)}

The specific conductivities change with the total surfactant concentration and with temperature. The specific conductivity increases sharply in the pre-micellar region with the surfactant concentration, but is somewhat reduced at certain concentrations, which reflects the CMC. The CMC values were computed from the slopes of $[\mathrm{Cr}(\mathrm{III})]$ versus specific conductance data. The complex concentration at which the micellization starts is evident from the change in the slope of the plot and that particular concentration is the $\mathrm{CMC}$ under the experimental conditions. The CMC values were measured at three different temperatures (303, 308 and $313 \mathrm{~K}$ ). At all temperatures a break in the conductance versus concentration plots, characteristic of micelle formation was observed. The CMC values were determined by fitting the data points above and below the break to two equations of the

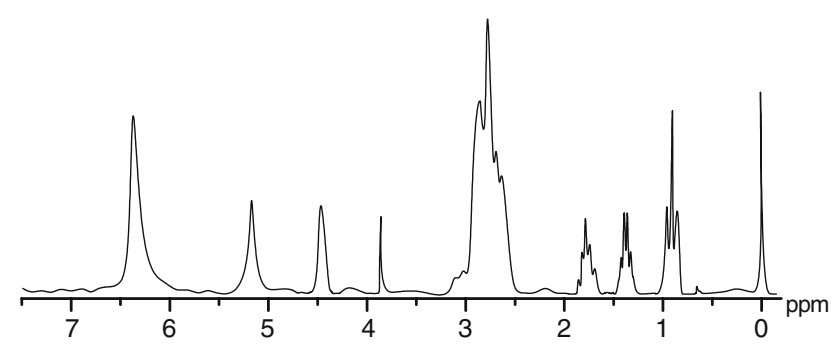

Fig. 1. ${ }^{1} \mathrm{H}-\mathrm{NMR}$ Spectrum of cis- $\left[\mathrm{Cr}(\mathrm{en})_{2}\left(\mathrm{C}_{16} \mathrm{H}_{33} \mathrm{NH}_{2}\right) \mathrm{Cl}\right]\left(\mathrm{ClO}_{4}\right)_{2}$. form $y=m x+c$ and solving the two equations simultaneously to obtain the point of interaction. Least-squares analysis was employed and correlation coefficients were greater than 0.98 in all cases. The conductivity measurements at three different temperatures have been repeated three times and the accuracy of the CMC values was found to be within $\pm 3 \%$ error. Figure 2 illustrates the values for the complex cis- $\left[\mathrm{Cr}(\mathrm{en})_{2}\left(\mathrm{C}_{12} \mathrm{H}_{25} \mathrm{NH}_{2}\right) \mathrm{Cl}\right]\left(\mathrm{ClO}_{4}\right)_{2}$; similar plots (not shown) were obtained for all the remaining complexes. Table 2 shows the value of the CMCs of $\mathrm{Cr}^{(\mathrm{III})}$-ethylenediamine and $\mathrm{Cr}^{(\mathrm{III})}$-triethylenetetramine, respectively as a function of temperature. It is found that CMC values increases on increasing the temperature for a given system. This behavior may be related to two competitive effects. Firstly, a temperature increase causes a decrease in hydration in the hydrophilic group, which favors micellization. Secondly, a temperature increase also disrupts the water surrounding the hydrophobic group, and this retards micellization. The relative magnitude of these two opposing effects will determine cmc behavior. It is observed that by changing the ions from $\mathrm{F}^{-}$to $\mathrm{Br}^{-}$, cmc decreases. This may be due to the increase in size of the ion in the coordination sphere, which makes it more weakly hydrated. Weakly hydrated ions can be adsorbed more readily in the micellar surface that decreases the charge repulsion between the polar groups and thus facilitates micellization. Further, with the increase in the alkyl chain on the polar head group, the cmc again shows a decrease. This may be due to an increase in hydrophobic character of the molecule in the coordination sphere with that of dodecyl/cetylamine.

\section{Thermodynamics of micellization}

The study of CMC versus temperature is often undertaken to obtain information on hydrophobic and head group interactions. This involves deriving various

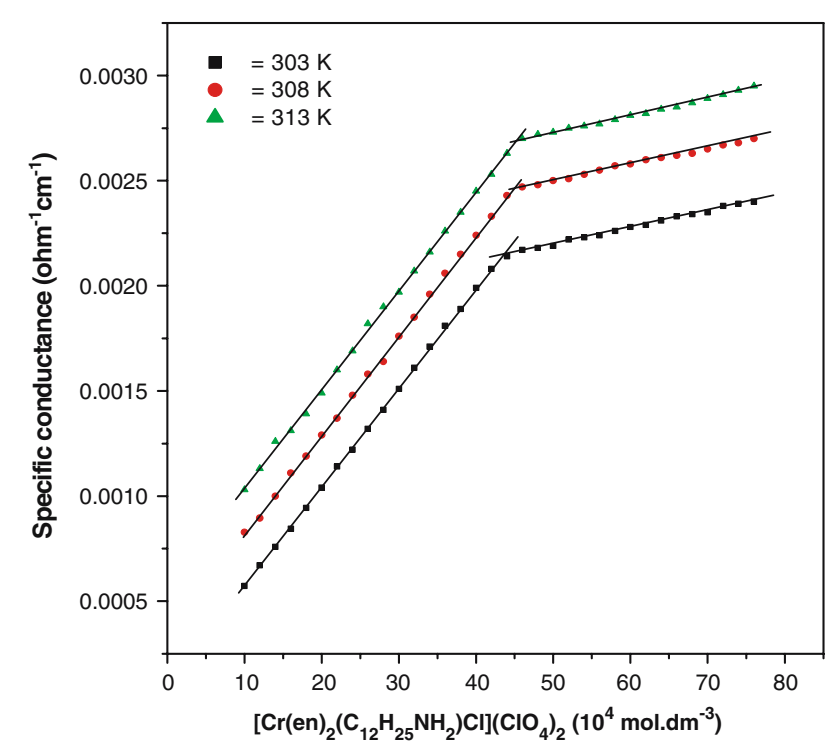

Fig. 2. Electrical conductivity versus $\left[\mathrm{Cr}^{(\mathrm{III})}\right]$ in aqueous solution. 
Table 2. CMC values of chromium(III) metallosurfactants in aqueous solution

\begin{tabular}{|c|c|c|c|c|c|c|}
\hline \multirow[t]{2}{*}{ Metallosurfactants } & \multicolumn{3}{|c|}{$\mathrm{CMC} \times 10^{4}\left(\mathrm{~mol} \mathrm{dm}^{-3}\right)$} & \multirow{2}{*}{$\Delta G_{\mathrm{m}}^{0}\left(\mathrm{~kJ} \mathrm{~mol}^{-1}\right)$} & \multirow[t]{2}{*}{$\Delta H_{\mathrm{m}}^{0}\left(\mathrm{~kJ} \mathrm{~mol}^{-1}\right)$} & \multirow[t]{2}{*}{$T \Delta S_{\mathrm{m}}^{0}\left(\mathrm{~kJ} \quad \mathrm{~mol}^{-1}\right)$} \\
\hline & $303 \mathrm{~K}$ & $308 \mathrm{~K}$ & $313 \mathrm{~K}$ & & & \\
\hline cis- $\left[\mathrm{Cr}(\mathrm{en})_{2}\left(\mathrm{C}_{12} \mathrm{H}_{25} \mathrm{NH}_{2}\right) \mathrm{F}\right]\left(\mathrm{ClO}_{4}\right)_{2}$ & $45.82 \pm 0.1$ & $46.21 \pm 0.1$ & $46.70 \pm 0.1$ & $-27.4 \pm 0.2$ & $-17.1 \pm 0.2$ & $10.3 \pm 0.1$ \\
\hline$c i s-\left[\mathrm{Cr}(\mathrm{en})_{2}\left(\mathrm{C}_{12} \mathrm{H}_{25} \mathrm{NH}_{2}\right) \mathrm{Cl}\right]\left(\mathrm{ClO}_{4}\right)_{2}$ & $43.33 \pm 0.2$ & $44.52 \pm 0.1$ & $45.15 \pm 0.2$ & $-27.3 \pm 0.3$ & $-18.2 \pm 0.1$ & $9.1 \pm 0.4$ \\
\hline$c i s-\left[\mathrm{Cr}(\mathrm{en})_{2}\left(\mathrm{C}_{12} \mathrm{H}_{25} \mathrm{NH}_{2}\right) \mathrm{Br}\right]\left(\mathrm{ClO}_{4}\right)_{2}$ & $42.11 \pm 0.1$ & $42.81 \pm 0.2$ & $43.64 \pm 0.1$ & $-27.3 \pm 0.5$ & $-23.4 \pm 0.1$ & $3.9 \pm 0.8$ \\
\hline cis- $\left[\mathrm{Cr}(\mathrm{en})_{2}\left(\mathrm{C}_{16} \mathrm{H}_{33} \mathrm{NH}_{2}\right) \mathrm{F}\right]\left(\mathrm{ClO}_{4}\right)_{2}$ & $8.50 \pm 0.2$ & $8.80 \pm 0.1$ & $9.42 \pm 0.2$ & $-42.3 \pm 0.1$ & $-30.3 \pm 0.3$ & $12.0 \pm 0.4$ \\
\hline cis- $\left[\mathrm{Cr}(\mathrm{en})_{2}\left(\mathrm{C}_{16} \mathrm{H}_{33} \mathrm{NH}_{2}\right) \mathrm{Cl}\right]\left(\mathrm{ClO}_{4}\right)_{2}$ & $7.43 \pm 0.1$ & $7.93 \pm 0.2$ & $8.31 \pm 0.1$ & $-42.2 \pm 0.1$ & $-33.2 \pm 0.1$ & $9.0 \pm 0.2$ \\
\hline$c i s-\left[\mathrm{Cr}(\mathrm{en})_{2}\left(\mathrm{C}_{16} \mathrm{H}_{33} \mathrm{NH}_{2}\right) \mathrm{Br}\right]\left(\mathrm{ClO}_{4}\right)_{2}$ & $6.31 \pm 0.1$ & $6.71 \pm 0.2$ & $7.12 \pm 0.1$ & $-42.3 \pm 0.2$ & $-36.4 \pm 0.1$ & $5.9 \pm 0.1$ \\
\hline cis- $\alpha-\left[\mathrm{Co}(\operatorname{trien})\left(\mathrm{C}_{12} \mathrm{H}_{25} \mathrm{NH}_{2}\right) \mathrm{F}\right]\left(\mathrm{ClO}_{4}\right)_{2}$ & $5.62 \pm 0.2$ & $5.68 \pm 0.1$ & $5.73 \pm 0.2$ & $-34.1 \pm 0.2$ & $-13.9 \pm 0.1$ & $20.2 \pm 0.2$ \\
\hline$c i s-\alpha-\left[\mathrm{Co}(\right.$ trien $\left.)\left(\mathrm{C}_{12} \mathrm{H}_{25} \mathrm{NH}_{2}\right) \mathrm{Cl}\right]\left(\mathrm{ClO}_{4}\right)_{2}$ & $5.37 \pm 0.1$ & $5.43 \pm 0.1$ & $5.49 \pm 0.1$ & $-33.7 \pm 0.4$ & $-15.2 \pm 0.3$ & $18.5 \pm 0.2$ \\
\hline$c i s-\alpha-\left[\mathrm{Co}(\right.$ trien $\left.)\left(\mathrm{C}_{12} \mathrm{H}_{25} \mathrm{NH}_{2}\right) \mathrm{Br}\right]\left(\mathrm{ClO}_{4}\right)_{2}$ & $5.09 \pm 0.1$ & $5.12 \pm 0.2$ & $5.18 \pm 0.2$ & $-33.2 \pm 0.1$ & $-15.7 \pm 0.2$ & $17.5 \pm 0.1$ \\
\hline cis- $\alpha-\left[\mathrm{Co}(\operatorname{trien})\left(\mathrm{C}_{16} \mathrm{H}_{33} \mathrm{NH}_{2}\right) \mathrm{F}\right]\left(\mathrm{ClO}_{4}\right)_{2}$ & $0.22 \pm 0.2$ & $0.25 \pm 0.2$ & $0.30 \pm 0.1$ & $-43.7 \pm 0.4$ & $-28.4 \pm 0.2$ & $15.3 \pm 0.4$ \\
\hline cis- $\alpha-\left[\mathrm{Co}(\operatorname{trien})\left(\mathrm{C}_{16} \mathrm{H}_{33} \mathrm{NH}_{2}\right) \mathrm{Cl}\right]\left(\mathrm{ClO}_{4}\right)_{2}$ & $0.21 \pm 0.1$ & $0.23 \pm 0.1$ & $0.27 \pm 0.1$ & $-43.5 \pm 0.2$ & $-30.3 \pm 0.1$ & $13.2 \pm 0.2$ \\
\hline cis- $\alpha-\left[\mathrm{Co}(\right.$ trien $\left.)\left(\mathrm{C}_{16} \mathrm{H}_{33} \mathrm{NH}_{2}\right) \mathrm{Br}\right]\left(\mathrm{ClO}_{4}\right)_{2}$ & $0.19 \pm 0.1$ & $0.21 \pm 0.1$ & $0.24 \pm 0.2$ & $-43.5 \pm 0.2$ & $-31.7 \pm 0.1$ & $11.8 \pm 0.2$ \\
\hline
\end{tabular}

thermodynamic parameters of micelle formation. Two models are generally used, the mass-action or equilibrium model and the phase separation or pseudo-phase model. The mass-action model assumes that an equilibrium exists between the monomeric surfactant and the micelles. The phase separation model, assumes that the aggregates with its counterions in the surrounding atmosphere in a separate phase [38-40]. According to these models, the standard Gibbs free energy of micelle formation per mole of monomer, $\Delta G_{\mathrm{m}}^{0}$, is given by

$$
\Delta G_{\mathrm{m}}^{0}=R T\left(2-\alpha_{\mathrm{ave}}\right) \ln \mathrm{cmc}
$$

where $R, T$ and $\alpha_{\text {ave }}$ are gas constant, absolute temperature and average degree of micellar ionization, respectively.

The enthalpy of micelle formation can be obtained by applying the Gibbs-Helmholtz equation to Equation (1):

$$
\Delta H_{\mathrm{m}}^{0}=-R T^{2}\left(2-\alpha_{\text {ave }}\right) \mathrm{d} \ln \mathrm{cmc} / \mathrm{d} T
$$

Once the Gibbs free energy and the enthalpy of micelle formation are obtained, obviously, the entropy of micelle formation can be determined by (3).

$$
\Delta S_{\mathrm{m}}^{0}=\left(\Delta H_{\mathrm{m}}^{0}-\Delta G_{\mathrm{m}}^{0}\right) / T
$$

The thermodynamic parameters of micellization for cationic surfactant with variable head group polarity are compiled in Table 2. The more negative Gibbs free energy of micellization observed for the surfactants with increasing head polarity indicates more favored micellization. Moreover, since the changes of CMC with temperature are small, the value of $\Delta H_{\mathrm{m}}^{0}$ and $\Delta S_{\mathrm{m}}^{0}$ must be rather inaccurate and should be considered as only approximate. Negative values of enthalpy $\left(\Delta H_{\mathrm{m}}^{0}\right)$ of micellization indicate exothermic nature of micellization process. Nuselder and Engberts [41] have suggested that for the negative $\Delta H_{\mathrm{m}}^{0}$ the London-dispersion forces play major role in the micelle formation. The positive values of $\Delta S_{\mathrm{m}}^{0}$ clearly indicate that the micellization of the studied surfactants in aqueous solution is governed mainly by hydrophobic interactions between the surfactant cations resulting in the breakdown of the structured water surrounding the hydrophobic groups and indicates that the cationic surfactants are entropy driven processes. The observed increase in the entropy values indicates that increasing head group polarity favors micellization the process.

\section{Conclusion}

As mentioned in our previous reports [6, 7], the critical micelle concentration values of chromium(III)-surfactant coordination complexes in the present study were also very low compared to that of the simple organic surfactant, dodecylammonium chloride $(\mathrm{CMC}=$ $1.5 \times 10^{-2} \mathrm{~mol} \mathrm{dm}^{-3}$ ). Thus it is concluded that these metal-surfactant complexes have more capacity to associate themselves forming aggregates compared to those of ordinary synthetic organic surfactants. This suggests that the introduction of a metal complex to the hydrophilic part of the amphiphile can remarkably enhance the ability of aggregation.

\section{Acknowledgements}

Sponsorship of this work by the University Grants Commission (No.F.12-9/2001/SR-I) is gratefully acknowledged.

\section{References}

1. T.F. Tadros, Applied Surfactants, 1, Wiley-VCH, Germany, 2005.

2. M.J. Rosen, Surfactants and Interfacial Phenomenon, 2, John Wiley, New York, 1988.

3. J.H. Fendler and E.J. Fendler, Catalysis in Micellar and Macromolecular Systems, Academic Press, New York, 1975.

4. G.W. Walker, R.J. Geue, A.M. Sargeson and C.A. Behm, J. Chem. Soc. Dalton Trans., 15, 2992 (2003).

5. D.A. Jaeger, M.F. Peacock and D. Scoot Bohle, Langmuir, 19, 4859 (2003).

6. M.N. Arumugam, K. Santhakumar, N. Kumaraguru and S. Arunachalam, Asian J. Chem., 15, 191-991 (2003). 
7. M.N. Arumugam and S. Arunachalam, Indian J. Chem., 36A, 84 and 315 (1997).

8. M. Iida, A. Sakamoto, T. Yamashita, K. Shundoh, S. Ohkawa and K. Yamanari, Bull. Chem. Soc. Jpn., 73, 2033 (2000).

9. D.A. Jaeger, V.B. Reddy and D. Scott Bohle, Tetrahedron Lett., 40, 649 (1999).

10. D.A. Jaeger, V.B. Reddy, N. Arulsamy and D. Scott Bohle, Langmuir, 14, 2589 (1998) and references therein.

11. M.E. Karaman, R.M. Pashley and N.K. Bolonkin, Langmuir, 11, 2872 (1995).

12. D.W. Bruce, I.R. Denby, G.J.T. Tiddy and J.M. Watkins, J. Mater. Chem., 3, 911 (1993).

13. M. Yashiro, K. Matsumoto, N. Seki and S. Yoshikawa, Bull. Chem. Soc. Jpn., 66, 1559 (1993).

14. M. Yashiro, K. Matsumoto and S. Yoshikawa, Chem. Lett., 1429 (1992).

15. M. Yashiro, K. Matsumoto and S. Yoshikawa, Chem. Lett., 985 (1989).

16. C.A. Behm, I.I. Creaser, B. Korybut-Daszkiewicz, R.J. Geue, A.M. Sargeson and G.W. Walker, J. Chem. Soc., Chem. Commun., 24, 1844 (1993).

17. C.A. Behm, P.F.L. Boreham, I.I. Creaser, B. Korybut-Daszkiewicz, D.J. Maddalena, A.M. Sargeson and G.M. Snowdown, Aust. J. Chem., 48, 1009 (1995).

18. G. Ghirlanda, P. Scrimin, P. Tecilla and A. Toffoletti, Langmuir, 14, 1646 (1998).

19. J.H. Fendler, Membrane Mimetic Chemistry, Wiley, New York, 1982.

20. A.M. Sargeson, Coord. Chem. Rev., 151, 89 (1996).

21. J. Qing, S. Qing Cheng, B. Ying Jiang, J. Du, C. Wei Hu and X. Cheng Zeng, Colloids Surf. A, 235, 137 (2004).

22. J. Song Yu, X. Qi Yu, X. Yu Su, T. Wang, Q.X. Xiang, M. Yang and R. Gang Xie, J. Mol. Catal. A: Chem., 202, 17 (2003).
23. S.A. Sapp, C.M. Eillott, C. Contado, S. Caramori and C.A. Bignozzi, J. Am. Chem. Soc., 124, 11215 (2002).

24. P.J. Cameron, L.M. Peter, S.M. Zakeeruddin and M. Gratzel, Coord. Chem. Rev., 248, 1447 (2004).

25. J.W. Vaughn, O.J. Stvan and V.E. Magnuson, Inorg. Chem., 7, 736 (1968).

26. K.R.A. Fehrmann and C.S. Garner, J. Am. Chem. Soc., 82, 6294 (1960).

27. D.A. House and C.S. Garner, J. Am. Chem. Soc., 88, 2156 (1966).

28. W.A. Fordyce, P.S. Sheridan, E. Zinato, P. Riccieri and A.W. Adamson, Inorg. Chem., 16, 1154 (1977).

29. T. Shedlovsky, J. Am. Chem. Soc., 54, 1411 (1932).

30. J.F. Chambers, J.M. Stokes and R.H. Stokes, J. Phys. Chem., 60, 985 (1956).

31. D.A. Buckingham and D. Jones, Inorg. Chem., 4, 1387 (1965).

32. M.N. Hughes and W.R. Mcwhinnie, J. Inorg. Nucl. Chem., 28, 1659 (1966).

33. M.E. Baldwin, J. Chem. Soc., 4369 (1960).

34. M.L. Morris and D.H. Busch, J. Am. Chem. Soc., 82, 1521 (1960).

35. Y. Yasui and Y. Shimura, Bull. Chem. Soc. Jpn., 36, 1286 (1963).

36. R.S. Nyholm and M.L. Tobe, J. Chem. Soc., 1707 (1956).

37. S.C. Chan and F. Leh, J. Chem. Soc., 760 (1966).

38. P. Mukerjee, J. Phys. Chem., 66, 1375 (1962).

39. J.J. Galan, A. Gonzalez-Perez and J.R. Rodriguez, J. Therm. Anal. Calorim., 72, 465 (2003).

40. A. Gonzalez-Perez, J.C. Del Castillo, T. Czapkiewicz and J.R. Rodrigue, Colloid Polym. Sci., 280, 503 (2002).

41. J.J.H. Nusselder and J.B.F.N. Engberts, J. Colloid Interface Sci., 148, 353 (1992).

TMCH 6400 